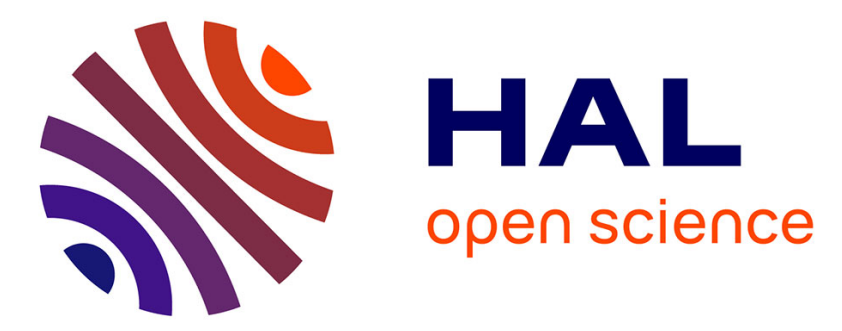

\title{
A methodology for optimal sizing of autonomous hybrid $\mathrm{PV} /$ wind system
}

Said. Diaf, Djamila Diaf, Mayouf Belhamel, Mourad Haddadi, Alain Louche

\section{To cite this version:}

Said. Diaf, Djamila Diaf, Mayouf Belhamel, Mourad Haddadi, Alain Louche. A methodology for optimal sizing of autonomous hybrid PV/wind system. Energy Policy, 2007, 35, pp.5708-5718. 10.1016/j.enpol.2007.06.020 . hal-00183357

\section{HAL Id: hal-00183357 https://hal.science/hal-00183357}

Submitted on 30 Oct 2007

HAL is a multi-disciplinary open access archive for the deposit and dissemination of scientific research documents, whether they are published or not. The documents may come from teaching and research institutions in France or abroad, or from public or private research centers.
L'archive ouverte pluridisciplinaire HAL, est destinée au dépôt et à la diffusion de documents scientifiques de niveau recherche, publiés ou non, émanant des établissements d'enseignement et de recherche français ou étrangers, des laboratoires publics ou privés. 


\title{
A methodology for optimal sizing of autonomous
}

\section{hybrid PV/wind system}

\author{
S. Diaf ${ }^{1 *}$, D. Diaf ${ }^{2}$, M. Belhamel ${ }^{2}$, M. Haddadi ${ }^{3}$, A. Louche $^{1}$ \\ ${ }^{1}$ Université de Corse CNRS -UMR 6134 Vignola -Route des Sanguinaires, Ajaccio, France \\ Email: sdiaf@hotmail.com \\ ${ }^{2}$ Centre of Renewable Energies Development, B.P. 6216340 Bouzareah Algiers, Algeria \\ ${ }^{3}$ Ecole Polytechnique d'El harrach, Algiers, Algeria
}




\begin{abstract}
The present paper presents a methodology to perform the optimal sizing of an autonomous hybrid PV/wind system. The methodology aims at finding the configuration, among a set of systems components, which meets the desired system reliability requirements, with the lowest value of levelised cost of energy.

Modelling a hybrid PV/wind system is considered as the first step in the optimal sizing procedure. In this paper, more accurate mathematical models for characterizing PV module, wind generator and battery are proposed. The second step consists to optimize the sizing of a system according to the loss of power supply probability (LPSP) and the levelised cost of energy (LCE) concepts.
\end{abstract}

Considering various types and capacities of system devices, the configurations which can meet the desired system reliability are obtained by changing the type and size of the devices systems. The configuration with the lowest LCE gives the optimal choice.

Applying this method to an assumed PV/wind hybrid system to be installed at Corsica Island, the simulation results show that the optimal configuration which meet the desired system reliability requirements (LPSP $=0$ ) with the lowest LCE is obtained for a system comprising a $125 \mathrm{~W}$ photovoltaic modules, one wind generator $(600 \mathrm{~W})$ and storage batteries (using $253 \mathrm{Ah}$ ), on other hand, the device system choice play an important role in cost reduction as well as in energy production

Keywords: optimum system sizing; loss of power load probability; levelised cost of energy 


\section{Introduction}

Since the oil crisis in the early 1970s, utilization of solar and wind power has became increasingly significant, attractive and cost-effective. In recent years, hybrid PV/wind system (HPWS) has became viable alternatives to meet environmental protection requirement and electricity demands. With the complementary characteristics between solar and wind energy resources for certain locations, hybrid PV/wind system with storage banks presents an unbeatable option for the supply of small electrical loads at remote locations where no utility grid power supply. Since they can offer a high reliability of power supply, their applications and investigations gain more concerns nowadays.(Yang, 2003).

Due to the stochastic behaviour of both solar and wind energy, the major aspects in the design of the hybrid PV/wind system are the reliable power supply of the consumer under varying atmospheric conditions and the cost of the $\mathrm{kWh}$ of energy.

To use solar and wind energy resources more efficiently and economically, the optimal sizing of hybrid PV/wind system with battery plays an important role in this respect.

Various optimization techniques of hybrid PV/wind systems sizing have been reported in the literature such as linear programming (Kellogg et al., 1996; Chedid et al., 1996), probabilistic approach (Karaki et al.,1999; Bagul et al.,1996), iterative technique (Kellogg et al., 1996) dynamic programming (Musgrove, 1988), multi-objective (Yokoyama et al., 1994). Using the autonomy level of the system, the set different configurations which meet the load are obtained (Yang et al., 2003; Beyer et al., 1996). In (Protogeropoulos et al., 1997), the author developed general methodology by considering design factor such as autonomy for sizing and optimization. 
In this context, the present study presents a methodology for the optimal sizing of autonomous $\mathrm{PV} /$ wind systems with storage batteries. The methodology adopted, taken as the favourite approach, is to suggest, among a set of systems components, the optimal number and type of units in terms of technical and economical concepts; the loss of power supply probability (LPSP) and the levelised cost of energy (LCE).

This paper is organised as follows;

First, the mathematical model of hybrid PV/wind system, including PV modules, wind generators and batteries storage, is developed. Secondly, the system reliability model, which is based on LPSP technique, and the system economical model, based on the LCE concept are presented. Lastly, the simulation results and conclusion are presented.

In the simulation, three sizing parameters are considered, i.e. the power PV module, rated power of wind generator and the storage capacity.

With the incorporated hybrid PV/wind system optimization model, the sizing optimization can be achieved technically and economically.

\section{Modeling of the hybrid PV/Wind system components}

Modelisation is an essential step before any phase of optimal sizing. Various modeling techniques are developed, to model HPWS components, in previous studies. For a hybrid $\mathrm{PV} /$ wind system with storage battery, as shown in Fig.1, three principal subsystems are included, the PV generator, the wind turbine and the battery storage. A methodology for modelling HPWS components is described below. 


\subsection{Modeling of PV generator}

As the operation and the performance of PV generator is interested to its maximum power, the models describing the PV module's maximum power output behaviours are more practical for PV system assessment. In this paper, a mathematical model for estimating the power output of PV modules is used. The estimation is carried out using a computer program which uses a subroutine for determining the power output of a PV module. Using the solar radiation available on the tilted surface, the ambient temperature and the manufacturers data for the PV modules as model inputs, the power output of the PV generator, $\mathrm{P}_{\mathrm{PV}}$, can be calculated according to the following equations (Markvard, 2000):

$$
\mathrm{P}_{\mathrm{PV}}=\eta_{\mathrm{g}} \mathrm{NA}_{\mathrm{m}} \mathrm{G}_{\mathrm{t}}
$$

Where, $\eta_{\mathrm{g}}$ is the instantaneous PV generator efficiency, $A_{m}$ is the area of a single module used in a system $\left(\mathrm{m}^{2}\right), G_{t}$ is the global irradiance incident on the titled plane $\left(\mathrm{W} / \mathrm{m}^{2}\right)$ and $\mathrm{N}$ is the number of modules.

All the energy losses in a PV generator, including connection losses, wiring losses and other losses, are assumed to be zero.

The instantaneous PV generator efficiency is represented by the following equation (Habib et al., 1999):

$$
\eta_{\mathrm{g}}=\eta_{\mathrm{r}} \eta_{\mathrm{pt}}\left[1-\beta_{\mathrm{t}}\left(\mathrm{T}_{\mathrm{c}}-\mathrm{T}_{\mathrm{r}}\right)\right]
$$

Where $\eta_{\mathrm{r}}$ is the PV generator reference efficiency, $\eta_{\mathrm{pt}}$ is the efficiency of power tracking equipment which is equal to 1 if a perfect maximum power point tracker is used, $T_{c}$ is the 
temperature of $\mathrm{PV}$ cell $\left({ }^{\circ} \mathrm{C}\right), \mathrm{T}_{\mathrm{r}}$ is the $\mathrm{PV}$ cell reference temperature and $\beta_{\mathrm{t}}$ is the temperature coefficient of efficiency, ranging from 0.004 to 0.006 per ${ }^{\circ} \mathrm{C}$ for silicon cells. Based on the energy balance proposed by (Duffie et al., 1991), the PV cell temperature can be expressed as follows:

$$
\mathrm{T}_{\mathrm{c}}=\mathrm{T}_{\mathrm{a}}+\mathrm{G}_{\mathrm{t}}\left(\frac{\tau \alpha}{\mathrm{U}_{\mathrm{L}}}\right)
$$

where

$\mathrm{T}_{\mathrm{a}}$, is the ambient temperature $\left({ }^{\circ} \mathrm{C}\right), \mathrm{U}_{\mathrm{L}}$ is the overall heat loss coefficient $\left(\mathrm{W} / \mathrm{m}^{2}\right.$ per $\left.{ }^{\circ} \mathrm{C}\right)$, $\tau$ and $\alpha$ represent, respectively, the transmittance and absorptance coefficients of PV cells. The overall heat loss coefficient $\left(\tau \alpha / \mathrm{U}_{\mathrm{L}}\right)$ can be estimated from the nominal operating cell temperature (NOCT) as follows (Chedid et al., 1996; Duffie et al., 1991):

$$
\left(\frac{\tau \alpha}{\mathrm{U}_{\mathrm{L}}}\right)=\frac{\mathrm{NOCT}-20}{800}
$$

Consequently, the instantaneous PV generator efficiency can be expressed as follows:

$$
\eta_{\mathrm{g}}=\eta_{\mathrm{r}} \eta_{\mathrm{pt}}\left\{1-\beta_{\mathrm{t}}\left(\mathrm{T}_{\mathrm{a}}-\mathrm{T}_{\mathrm{r}}\right)-\beta_{\mathrm{t}} \mathrm{G}_{\mathrm{t}}\left(\frac{\mathrm{NOCT}-20}{800}\right)\left(1-\eta_{\mathrm{r}} \eta_{\mathrm{pt}}\right)\right\} .
$$

$\eta_{\mathrm{pt}}, \beta_{\mathrm{t}}$, NOCT, $\mathrm{A}_{\mathrm{m}}$ are parameters that depend on the type of module, and given by the manufacturer of the modules.

\subsection{Modeling of wind generator}

Different wind generators have different power output performance curves. Therefore, the model used to describe the performance of wind generators is expected to be different. 
Some authors (Yang et al., 2002; Chedid et al., 19981; Eftichios et al., 2006; Lysen, 1983) assume that the turbine power curve has a linear, quadratic or cubic form. Other authors (Troen et al., 1989; Bueno, 2005) approximate the power curve with a piecewise linear function with a few nodes. In other case studies, a model which has a similar form is applied taking into account the Weibull parameters (Bogdan et al., 1996; Borowy et al., 1994).

Previous models are often used for the simulation and evaluation of wind power generation systems in field applications. However, for a specific wind generator, a model should be developed according to its power output performance curve, which is given by the manufacturer.

In this paper, the wind generator power output is estimated through interpolation of the values of the data provided by the manufacturers. As the power curves are quite smooth, they can be approximated using a cubic spline interpolation (Akai, 1994).

The fitting equation of the output characteristic of wind generator can be expressed as:

$$
\left.\mathrm{P}_{\mathrm{WG}} \mathrm{V}\right)=\left(\begin{array}{ll}
0 & \mathrm{~V} \leq \mathrm{V}_{\mathrm{ci}} \text { or } \mathrm{V} \geq \mathrm{V}_{\mathrm{co}} \\
\mathrm{a}_{1} \mathrm{~V}^{3}+\mathrm{b}_{1} \mathrm{~V}^{2}+\mathrm{c}_{1} \mathrm{~V}+\mathrm{d}_{1} & \mathrm{~V}_{\mathrm{ci}}<\mathrm{V}<\mathrm{V}_{1} \\
\mathrm{a}_{2} \mathrm{~V}^{3}+\mathrm{b}_{2} \mathrm{~V}^{2}+\mathrm{c}_{2} \mathrm{~V}+\mathrm{d}_{2} & \mathrm{~V}_{1}<\mathrm{V}<\mathrm{V}_{2} \\
\cdots \cdots \cdots \cdots \cdots \cdots \cdots \cdots \cdots \cdots \cdots \cdots \cdots \cdots \cdots \cdots \cdots \cdots & \\
\mathrm{a}_{\mathrm{n}} \mathrm{V}^{3}+\mathrm{b}_{\mathrm{n}} \mathrm{V}^{2}+\mathrm{c}_{\mathrm{n}} \mathrm{V}+\mathrm{d}_{\mathrm{n}} & \mathrm{V}_{\mathrm{n}-\mathrm{i}}<\mathrm{V}<\mathrm{V}_{\mathrm{r}} \\
\mathrm{P}_{\mathrm{r}} & \mathrm{V}_{\mathrm{r}} \leq \mathrm{V}<\mathrm{V}_{\mathrm{co}}
\end{array}\right.
$$

Where $\mathrm{P}_{\mathrm{WG}}(\mathrm{V})$ is the output power of wind generator at wind speed $\mathrm{V}, \mathrm{P}_{\mathrm{r}}$ is the rated power; $\mathrm{V}$ is the wind speed at the hub height $\mathrm{V}_{\mathrm{ci}}, \mathrm{V}_{\mathrm{r}}$ and $\mathrm{V}_{\text {co }}$ are the cut-in, rated and cutout wind speeds, respectively. 
$\mathrm{n}$ is the number of cubic spline interpolation functions corresponding to $\mathrm{n}+1$ values couples (speed, power) of data provided by the manufacturers; a, b, c and d are the polynomial coefficients of the cubic spline interpolation functions which depend on the wind turbine generator type.

As the installation height of the wind turbine has a large effect on the energy available from the system, the adjustment of the wind profile for height can be taken into account by using a height adjustment equation. In this study, the power law is applied for the vertical wind speed profile, as shown in equation below (Ilinka et al., 2003).

$$
\mathrm{V}=\mathrm{V}_{0}\left(\frac{\mathrm{H}}{\mathrm{H}_{0}}\right)^{\alpha_{1}}
$$

Where $\mathrm{V}$ is the wind speed at hub height $\mathrm{H}, \mathrm{V}_{0}$ is the wind speed measured at the reference height $\mathrm{H}_{0}$ and $\alpha_{1}$ is the power law exponent which varies with the elevation, the time of day, the season, the nature of the terrain, the wind speed and the temperature. According to many authors, the typical value of $1 / 7$ corresponding to low roughness surfaces and well exposed sites, is used in this study (Ilinka et al., 2003; Johnson, 1985).

\subsection{Modeling of battery storage}

At any hour the state of battery is related to the previous state of charge and to the energy production and consumption situation of the system during the time from t- 1 to t. During the charging process, when the total output of PV and wind generators is greater than the load demand, the available battery bank capacity at hour $\mathrm{t}$ can be described by (Bogdan et al., 1996; Bin et al., 2003): 


$$
\mathrm{C}_{\text {bat }}(\mathrm{t})=\mathrm{C}_{\text {bat }}(\mathrm{t}-1) \cdot(1-\sigma)+\left(\mathrm{E}_{\mathrm{PV}}(\mathrm{t})+\mathrm{E}_{\mathrm{WG}}(\mathrm{t})-\frac{\mathrm{E}_{\mathrm{L}}(\mathrm{t})}{\eta_{\text {inv }}}\right) \eta_{\text {bat }}
$$

On the other hand, when the load demand is greater than the available energy generated, the battery bank is in discharging state. Therefore, the available battery bank capacity at hour $\mathrm{t}$ can be expressed as:

$$
\mathrm{C}_{\text {bat }}(\mathrm{t})=\mathrm{C}_{\text {bat }}(\mathrm{t}-1) \cdot(1-\sigma)-\left(\frac{\mathrm{E}_{\mathrm{L}}(\mathrm{t})}{\eta_{\text {inv }}}-\left(\mathrm{E}_{\mathrm{PV}}(\mathrm{t})+\mathrm{E}_{\mathrm{WG}}(\mathrm{t})\right)\right)
$$

Where $\mathrm{C}_{\text {bat }}(\mathrm{t})$ and $\mathrm{C}_{\text {bat }}(\mathrm{t}-1)$ are the available battery bank capacity $(\mathrm{Wh})$ at hour $\mathrm{t}$ and $\mathrm{t}$ 1 , respectively; $\eta_{\text {bat }}$ is the battery efficiency (during discharging process, the battery discharging efficiency was set equal to 1 and during charging, the efficiency is 0.65 to 0.85 depending on the charging current) (Bin et al., 2003).

$\sigma$ is self-discharge rate of the battery bank. The manufacturer documentation gives a self discharge of $25 \%$ over six months for a storage temperature of $20{ }^{\circ} \mathrm{C}$, that is to say $0.14 \%$ per day (Markvart et al., 2003).

$\mathrm{E}_{\mathrm{PV}}(\mathrm{t})$ and $\mathrm{E}_{\mathrm{WG}}(\mathrm{t})$ are the energy generated by $\mathrm{PV}$ and wind generators, respectively; $\mathrm{E}_{\mathrm{L}}(\mathrm{t})$ is the load demand at hour $\mathrm{t}$ and $\eta_{i n v}$ is the inverter efficiency (in this study it is considered as constant, 92\%).

At any hour, the storage capacity is subject to the following constraints:

$$
\mathrm{C}_{\text {bat min }} \leq \mathrm{C}_{\text {bat }}(\mathrm{t}) \leq \mathrm{C}_{\text {bat max }}
$$

Where $\mathrm{C}_{\text {batmax }}$ and $\mathrm{C}_{\text {batmin }}$ are the maximum and minimum allowable storage capacity.

Using for $\mathrm{C}_{\text {bat max }}$ the storage nominal capacity $\mathrm{C}_{\text {batn }}$, then

$$
\mathrm{C}_{\text {batmin }}=\text { DOD. } \mathrm{C}_{\text {batn }}
$$


where DOD (\%) represents the maximum permissible depth of battery discharge.

\section{Modeling of system reliability}

Several approaches are used to achieve the optimal configurations of hybrid systems in term of technical analysis. Among these methods, we find the least square method applied by (Kellogg et al., 1996; Borowy et al., 1994), the trade-off method (Gavanidou et al., 1993; Elhadidy et al., 1999) and the technical approach also called loss of power supply probability (LPSP) (Yang et al., 2002; Abouzahr et al., 1990, 1991; Hongxing et al., 2002). In this study, the technical sizing model for the HPWS is developed according to the concept of LPSP to evaluate the reliability of hybrid systems. The methodology used can be summarized in the following steps.

The total power, $\mathrm{P}_{\text {tot }}(\mathrm{t})$, generated by the wind turbine and PV generator at hour $\mathrm{t}$ is calculated as follows:

$$
P_{\text {tot }}(t)=P_{P V}(t)+P_{W G}(t)
$$

Then, the inverter input power, $\mathrm{P}_{\text {inv }}(\mathrm{t})$, is calculated using the corresponding load power requirements, as follows:

$$
\mathrm{P}_{\text {inv }}(\mathrm{t})=\frac{\mathrm{P}_{\text {load }}(\mathrm{t})}{\eta_{\text {inv }}}
$$

where $P_{\text {load }}(t)$ is the power consumed by the load at hour $t, \eta_{\text {inv }}$ is the inverter efficiency. During this operation of the hybrid PV/wind system, different situations may appear:

a) the total power generated by the PV and Wind generators is greater than the power needed by the load, $\mathrm{P}_{\text {inv }}$. In this case, the energy surplus is stored in 
the batteries and the new storage capacity is calculated using Eq.8. until the full capacity is obtained, the remainder of the available power is not used

b) The total PV and wind generators power is less than the power needed by the load, $\mathrm{P}_{\text {inv }}$, the energy deficit is covered by the storage and a new battery capacity is calculated using Eq. 9.

c) In case of inverter input and total power equality, the storage capacity remains unchanged.

In case (a) when the battery capacity reaches a maximum value, $\mathrm{C}_{\text {bat max }}$, the control system stops the charging process.

The wasted energy, defined as the energy produced and not used by the system, for hour $t$ is calculated as follows:

$$
\mathrm{WE}(\mathrm{t})=\mathrm{P}_{\text {tot }}(\mathrm{t}) \Delta \mathrm{t}-\left(\frac{\mathrm{P}_{\text {load }}(\mathrm{t})}{\eta_{\text {inv }}} \Delta \mathrm{t}+\left(\frac{\mathrm{C}_{\text {batmax }}-\mathrm{C}_{\text {bat }}(\mathrm{t}-1)}{\eta_{\text {cha }}}\right)\right)
$$

In case (b), if the battery capacity decreases to their minimum level, $\mathrm{C}_{\mathrm{batmin}}$, the control system disconnects the load and the energy deficit, loss of power supply for hour $\mathrm{t}$ can be expressed as follows (Bogdan et al., 1996; Bin et al., 2003):

$$
\operatorname{LPS}(\mathrm{t})=\mathrm{P}_{\text {load }}(\mathrm{t}) \cdot \Delta \mathrm{t}-\left(\left(\mathrm{P}_{\mathrm{PV}}(\mathrm{t})+\mathrm{P}_{\mathrm{WG}}(\mathrm{t})\right) \Delta \mathrm{t}+\mathrm{C}_{\text {bat }}(\mathrm{t}-1)-\mathrm{C}_{\text {bat min }}\right) \cdot \eta_{\text {inv }}
$$

Where $\Delta \mathrm{t}$ is the step of time used for the calculations (in this study $\Delta \mathrm{t}=1$ hour). During that time, the power produced by the PV and wind generators are assumed constant. So, the power is numerically equal to the energy within this time step.

The loss of power supply probability, LPSP, for a considered period T, can be defined as the ratio of all the (LPS(t)) values over the total load required during that period. The LPSP 
technique is considered as technical implemented criteria for sizing a hybrid $\mathrm{PV} /$ wind system employing a battery bank. The technical model for hybrid system sizing is developed according to the LPSP technique. This can be defined as (Bin et al., 2003):

$$
\operatorname{LPSP}=\sum_{\mathrm{t}=1}^{\mathrm{T}} \operatorname{LPS}(\mathrm{t}) / \sum_{\mathrm{t}=1}^{\mathrm{T}} \mathrm{P}_{\text {load }}(\mathrm{t}) \Delta \mathrm{t}
$$

$\mathrm{T}$ is the operation time (in this study, $\mathrm{T}=$ one year).

In Fig. 2., the algorithm of the computer program used for this purpose is presented. The algorithm input data set consists of hourly solar irradiation on a tilted plane, hourly mean values of ambient temperature and wind speed, LPSP, load power requirements during the year and specifications of the system devices. Moreover, we can introduce for the analysis two more concepts:

The first one is the renewable contribution defined as the ratio of the load supplied by the hybrid PV/wind system during a given time period over the total load during the same period. According to the LPSP, it can be expressed as follows:

$$
\operatorname{RC}(\mathrm{T})=1-\text { LPSP }
$$

The second concept is the energy excess percentage which is defined as the wasted energy divided by the total energy produced by the PV and wind generators during the considered period.

$$
\operatorname{EXC}(T)=\frac{W E(T)}{E_{\text {tot }}(T)}
$$

For a given LPSP value and a defined period, many configurations can technically meet the required reliability demand of power supply. The optimal configuration can be identified 
finally from this set of configurations by achieving the lowest LCE. This can be performed by applying an economical model developed in the following section.

\section{Economical model}

Since more concerns are given to the lowest energy cost in such projects, the economical approach can be the best benchmark of cost analysis. Several methods are used to evaluate different options for energy system; the levelised cost of energy is often the preferred indicator (Nelson et al., 2005; Ramakumar et al., 1993). In this section, an economic sizing model is developed for the HPWS according to the LCE concept.

The levelised cost of energy is defined as (Athanasia et al., 2000):

$$
\mathrm{LCE}=\frac{\mathrm{TPV} \cdot \mathrm{CRF}}{\mathrm{E}_{\text {load }}}
$$

where, $\mathrm{E}_{\text {load }}$ is the yearly output in $\mathrm{kWh}, \mathrm{TPV}$ and $\mathrm{CRF}$ are the total present value of actual cost of all system components and the capital recovery factor, respectively, which can be expressed as follows (Athanasia et al., 2000):

$$
\begin{aligned}
& \mathrm{CRF}=\frac{\mathrm{i}(1+\mathrm{i})^{\mathrm{n}}}{(1+\mathrm{i})^{\mathrm{n}}-1} \\
& \mathrm{TPV}=\mathrm{C}_{\mathrm{pv}}+\mathrm{C}_{\text {wind }}+\mathrm{C}_{\text {bat }}
\end{aligned}
$$

where, $\mathrm{i}$ is the annual discount rate, $\mathrm{n}$ is the system life in years, $\mathrm{C}_{\mathrm{pv}}$ is the sum of present value of capital and maintenance costs of the PV generator in system life; $\mathrm{C}_{\text {wind }}$ is the sum of present value of capital and maintenance costs of the wind turbines in system life; $\mathrm{C}_{\mathrm{bat}}$ is the sum of present value of capital and replacement costs of battery bank in system life. 
The configuration with the lowest LCE is taken as the optimal one from the set of configurations which guarantee the required LPSP.

In this study, we assume that the system life is the life of the PV module and wind generator corresponding to 25 years and the storage system life is 4 years. Therefore, the battery storage will need to be replaced several times along the system lifetime, while the rest of the components can last the entire system life.

Additionally, the balance of system (BOS) costs, referred to support structure, power conditioning and interface units, installation and safety and control components, is taken as $25 \%$ of the cost of wind turbine and $50 \%$ of the cost of PV module. The annual maintenance cost has been set at $5 \%$ of capital cost for the wind turbine, $1 \%$ of capital cost for the PV generator and $0 \%$ for the batteries storage. The annual discount rate is considered as $8 \%$.

\section{Results and discussion}

The developed methodology has been applied to design a stand alone hybrid PV/wind system in order to power supply residential household located in the area of the Laboratory CNRS Ajaccio (Corsica island) $\left(41^{\circ} 55^{\prime} \mathrm{N}, 8^{\circ} 44^{\prime} \mathrm{E}\right)$.

The simulations are computed using one year (2001) of hourly global solar irradiations on tilted plane $\left(45^{\circ}\right)$, as well as hourly mean values of wind speeds and ambient temperature, given in Fig.3. The estimated hourly load profile is shown in Fig.4.

The wind and solar power are assumed to be constant during the time step (1 hour in this study). The technical and economical parameters of the components system are given in Table 1-3. 
As the first step, the system reliability model is developed in terms of the concept of LPSP. For this purpose, several simulations have been made by considering different combinations taking into account; the power of PV and wind generators and the capacity storage.

For an LPSP of 0 and a load profile defined in this study, the simulation results, based on the LPSP concept are presented in Fig. 5.

As shown in this figure, the different configurations which meet the same reliability of power supply are expressed by plotting the trade off curve between the PV generator power and battery capacity for each wind generator. Two domains can be identified if the storage capacity is less than $500 \mathrm{Ah}$, the variation of PV power on versus the capacity battery is important, and become gradual for capacity storage greater than $500 \mathrm{Ah}$. This can be explained because with low storage capacity, the system needs more PV power to meet the load with the desired LPSP.

In Fig. 6, the variation of the renewable contribution and the energy excess part as a function of the PV power for different wind generator sizes are presented.

According to the results obtained, the energy excess part increases with increasing wind generator number. This increase is inversely proportional to the photovoltaic power. Therefore, in the range of the PV power varying from 0 to $450 \mathrm{~W}$, the energy excess percentage is nearly zero for configuration including one wind generator and increase significantly with increasing wind generator number.

In addition, we can observe that the configurations including one wind generator, and whatever its power, lead to the same energy excess. 
An interesting conclusion drawn from Figs. 6 and 7 states that the renewable contribution trend, is a linear function of the power generator and is independent of the battery capacity. This fact is valid even for the large battery capacity.

To obtain a total renewable contribution $(\mathrm{RC}=1)$, more than $30 \%$ of the $\mathrm{PV}$ and wind energy production is unused unless the battery capacity is very large. A reduction in the renewable contribution decreases the unused energy.

The simulation results also show that with a renewable contribution of about $85 \%$, the energy excess percentage decreases to $5 \%$ for configuration with one wind generator, while it reaches a value below $15 \%$ for that of two generators.

Additionally, in order to asses the impact of battery storage on an energy excess percentage, the range of storage capacity is varied from $3 \mathrm{kWh}$ to $25 \mathrm{kWh}$ (equivalent to 1 to 8 times the daily consumption). The simulation results, presented in Fig. 7, for one wind generator $(600 \mathrm{~W})$ show that varying battery storage does not affect the energy excess parts. Therefore, the energy excess is due to the PV generator power, taking account the wind generator power.

It may then be conclude that three important cases can be identified:

- When the energy excess part is low, the load is not satisfied.

- In the second case, corresponding to the load satisfaction varying between $85 \%$ and $100 \%$, in spite of an energy excess, a third energy source (diesel generator) is needed to supply the load.

- In the third case, i.e. when the load is totally supplied with an important energy excess, while the satisfaction of load is total from a technical point of view, however, it is not from an energetically one. 
After the technical process, the levelised cost of energy is utilized to be the economic benchmark for simulation calculations in the HWPS model.

To obtain the hybrid PV/wind system with the lowest LEC, several simulations have been done using different capacities of wind generator, PV module and battery storage.

The simulation results representing the levelised costs of energy for different combinations satisfying an LPSP of 0 are presented in Figs. 8 and 9. The figures illustrate different combinations of $\mathrm{PV}$, wind and battery storage capacities and their corresponding $\mathrm{kWh}$ costs. The search algorithm yields only one combination for the optimum solution, where the cost of $\mathrm{kWh}$ energy is a minimum.

Firstly, using different types of PV module and storage battery, the simulation results related to the levelised cost of energy, are presented in Fig. 8.

These results show that the:

- PV power does not depend on the module power, but rather, by including an economical consideration, a $125 \mathrm{~W}$ module configuration is better than a $50 \mathrm{~W}$ one.

- configuration including battery storage (253 Ah) appears to be better than that using battery storage (102 Ah).

- From an economical point of view, optimal configuration is determined by the minimum of the cost function corresponding to an LPSP equal to zero.

Taking into account the results presented in Fig. 8 (configurations with $125 \mathrm{~W}$ module and 253 Ah battery are, economically, the best solution), the analysis is now limited only to these element types and for different system configurations. The results are presented in Fig. 9, they show that: 
- Using $125 \mathrm{~W}$ modules and different wind turbines confirms the result obtained previously with a minimal cost of the $\mathrm{kWh}$. It is interesting to note that using small wind turbines (600 $\mathrm{x} 3$ ) is cheaper than using one wind generator of $1000 \mathrm{~W}$.

- For different system configurations with $100 \%$ reliability, the lowest LCE happens with the same battery storage, which corresponds to the double capacity of daily energy consumption. The optimal sizing results are presented in Table 4.

- The levelised cost of energy depends on the components choice, and the economical solution is the configuration with one wind generator of $600 \mathrm{~W}$.

- As it can be seen in Fig. 8 and 9, the LCE curve has two linear parts. In the first part (below a storage battery of 750 Ah corresponding to three times capacity of daily energy consumption), a sharp decrease in the cost is observed which is mainly due to the decrease of PV power. In the second part, for a storage capacity of battery greater than $500 \mathrm{Ah}$, the LCE increases gradually with increasing the storage capacity. This increase is due to the short life of battery.

Finally, in Fig.10, the LCE is given as a function of excess energy part, according to these results; we can observe that an optimal value of excess energy part for which the LCE is minimum, exists. For all system configurations considered in this study, this value varies from 43 to $46 \%$, depending on the wind generator type. A reduction in the excess energy part, with the same conditions of the system reliability, increase the LCE.

In order to obtain the lowest LCE value with minimum energy excess, the use of a third energy source (diesel) could be beneficial for the system. This approach will be carried out in our future study. 


\section{Conclusion}

The optimal sizing of autonomous hybrid PV/wind system with battery storage, using an optimization model, has been developed in this work. The system configurations can be obtained in terms of a system power supply reliability requirement by using the LPSP concept. The one with the lowest levelised cost of energy is considered as the economical optimal configuration.

The simulation results, for a LPSP of 0 and a defined profile, show that in order to obtain a total renewable contribution $(\mathrm{RC}=1)$, more than $30 \%$ of the energy production is unused unless the battery capacity is very large. On the other hand, while in a renewable contribution of about $85 \%$, the energy excess percentage decreases to $5 \%$, for a configuration with one wind generator and below $15 \%$ for that comprising two generators. The second important conclusion is that the system devices choice represents an important step in the optimal sizing of the hybrid PV/wind system. Including economical consideration, a $125 \mathrm{~W}$ module configuration is found better than a $50 \mathrm{~W}$ one. However, the configuration system comprising one wind generator (600 W), PV generator (using 125 W modules) and batteries storage (using 253 Ah battery) is found as the optimal one from both the economical and technical point of view.

Additionally, for different system configurations with $100 \%$ reliability, the lowest LCE happens with the same battery capacity (750Ah), corresponding to the double daily capacity, and with an energy excess exceeding $40 \%$.

Finally, In order to reduce the energy excess, corresponding to the lowest LCE, the use of a third energy source (diesel) can bring benefit to the system. 


\section{References}

Abouzahr, I., Ramakumar. R. 1990. Loss of power supply probability of stand alone electric conversion systems: a closed form solution approach. IEEE Transaction on Energy Conv. 5(3), 445-452.

Abouzahr, I., Ramakumar. R. 1991. Loss of power supply probability of stand alone photovoltaic systems: a closed form solution approach. IEEE Transaction on Energy Conv. 6(1), 1-11.

Akai TJ. 1994. Applied numerical methods for engineers, second ed, John Wiley and Sons, New York.

Athanasia A. Lazou, Anastassios D. Papatsoris. 2000. The economics of PV stand-alone residential households: A case study for various European and Mediterranean locations; Solar Energy Materials and Solar Cells. 62 411-427.

Bagul AD, Salameh ZM, Borowy B. 1996. Sizing of stand-alone hybrid PV/wind system using a three-event probabilistic density approximation. Solar Energy 56(4), 323335.

Beyer HG, Langer C. 1996. A method for the identification of configurations of PV/wind hybrid systems for the reliable supply of small loads. Solar Energy 57(5), 381-391.

Bin, A., Hongxing, Y., Shen, H., Xianbo, L.2003. Computer aided design for PV/Wind hybrid system. Renewable Energy 28,1491-1512.

Bogdan, S. B. and Salameh, Z. M. 1996. Methodology for optimally sizing the combination of a battery bank and PV array in a wind/PV hybrid system. IEEE Transactions on Energy Conv. 11(2), 367-375. 
Borowy, B. S., Salameh., Z. M. 1994. Optimum photovoltaic array size for a hybrid wind/PV system. IEEE Transactions on Energy Conv. 9(3), 482-488.

Bueno C, Carta JA. 2005. Technical-economic analysis of wind-powered pumped hydrostorage systems. Part I: Model development. Solar Energy 78,382-395.

Chedid R, Saliba Y. 1996. Optimization and control of autonomous renewable energy systems. Int J Energy Res. 20, 609-624.

Chedid, R ., Rahman, S. 1998. A decision support technique for the design of hybrid solar wind power systems. IEEE Transactions on Energy Conv. 13(1), 76-83.

Duffie J. A. and Beckman W. A. 1991. Solar engineering of thermal of thermal process, the second ed., John Wiley and Sons, Inc., New York.

Eftichios K., Dionissia K., Antonis P., Kostas K. 2006. Methodology for optimal sizing of stand alone photovoltaic/wind generator systems using genetic algorithms. Solar Energy 80, 1072-1088.

Elhadidy, M.A., Shaahid, S. M., 1999. Optimal sizing of battery storage for hybrid (wind + diesel) power systems. Renewable Energy 18, 77-86.

Gavanidou, E. S., Bakirtzis A. G. 1993. Design of a stand alone system with renewable energy sources using trade off methods. IEEE Transactions on Energy Conv. 7(1), 42-48.

Gomma, S., Seoud, A. K. A., Kheiralla., H. N., 1995; Design and analysis of photovoltaic and wind energy hybrid systems in Alexandria, Egypt. Renewable Energy 6(5-6), 643-647.

Habib MA, Said S.1999. El-Hadidy MA, Al-Zaharna I. Optimization procedure of a hybrid photovoltaic wind energy system. Energy 24, 919-29. 
Hongxing, Y ; Lu, L., Burnett. L. J. 2002. Probability and reliability analysis of hybrid PV/wind power conversion system in Hong Kong. WREC. cologne Germany.

Ilinka, A., McCarthy, E., Chaumel, JL., Retiveau, JL. 2003. Wind potential assessment of Quebec Province. Renewable Energy 28(12),1881-1897.

Johnson GL. 1985. Wind energy systems. Englewood Cliffs, NJ,: Prentice-Hall. USA.

Karaki, SH., Chedid RB., Ramadan R. 1999. Probabilistic performance assessment of autonomous solar-wind energy conversion systems. IEEE Trans Energy Conv. 14(3), 766-772.

Kellogg, W., Nehrir, M.H., Venkataramanan, G., Gerez., V. 1996. Optimal unit sizing for a hybrid PV/wind generating system. Electric power system research 39, 35-38.

Lysen, E. H. 1983. Introduction to Wind Energy, second ed., SWD 82-1 Holland.

Markvard T. 2000. Solar electricity, the second ed, USA. Willey.

Markvart, T., Castaner., L. 2003. Practical hand book of Photovoltaic Fundamentals and applications.

Musgrove ARD. 1988. The optimization of hybrid energy conversion system using the dynamic programming model - RAPSODY. Int. J Energy Res. 12, 447-457.

Nelson, D.B, Nehrir, M. H., Wang. C. 2005. Unit Sizing of Stand Alone Hybrid Wind /PV/Fuel Cell Power Generation Systems. IEEE Power Engineering Society General Meeting (3), 2116-2122.

Protogeropoulos C, Brinkworth BJ, Marshall RH. 1997. Sizing and techno-economical optimization for hybrid solar PV/wind power systems with battery storage. Int J. Energy Res. 21, 465-479. 
Ramakumar, Nicholas, R., Butler, G., Alonso, Rodriguez, P., Mani, S. 1993. Economic Aspects of Advanced Energy Technologies. Proceedings of the IEEE. 81 (3).317333.

Troen, I, Petersen, EL. 1989. European wind atlas. First ed., Roskilde: Riso National Laboratory.

Yang, H.X., J. Burnett. L. Lu, 2003. Weather data and probability analysis of hybrid photovoltaic wind power generation systems in Hong Kong. Renewable Energy 28, $1813-1824$.

Yokoyama R, Ito K, Yuasa Y. 1994. Multi-objective optimal unit sizing of hybrid power generation systems utilizing PV and wind energy. J Solar Energy Eng. 116,167-173.

Yang Lu, L., Burnett, J. H.X. 2002. Investigation on wind power potential on Hong Kong islands-an analysis of wind power and wind turbine characteristics. Renewable Energy 27, 1-12. 


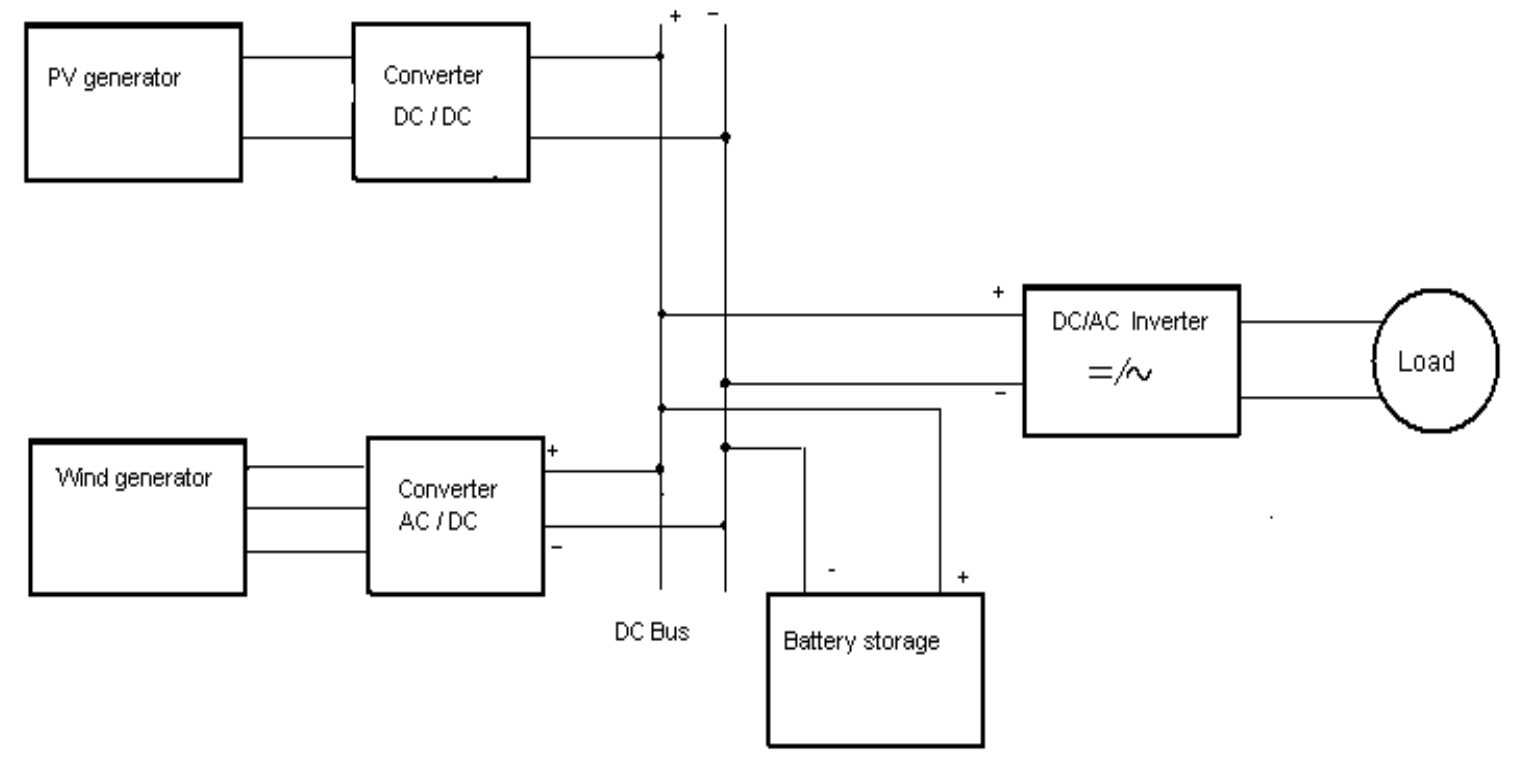

Fig. 1. Schematic diagram of hybrid PV/wind system with battery storage 


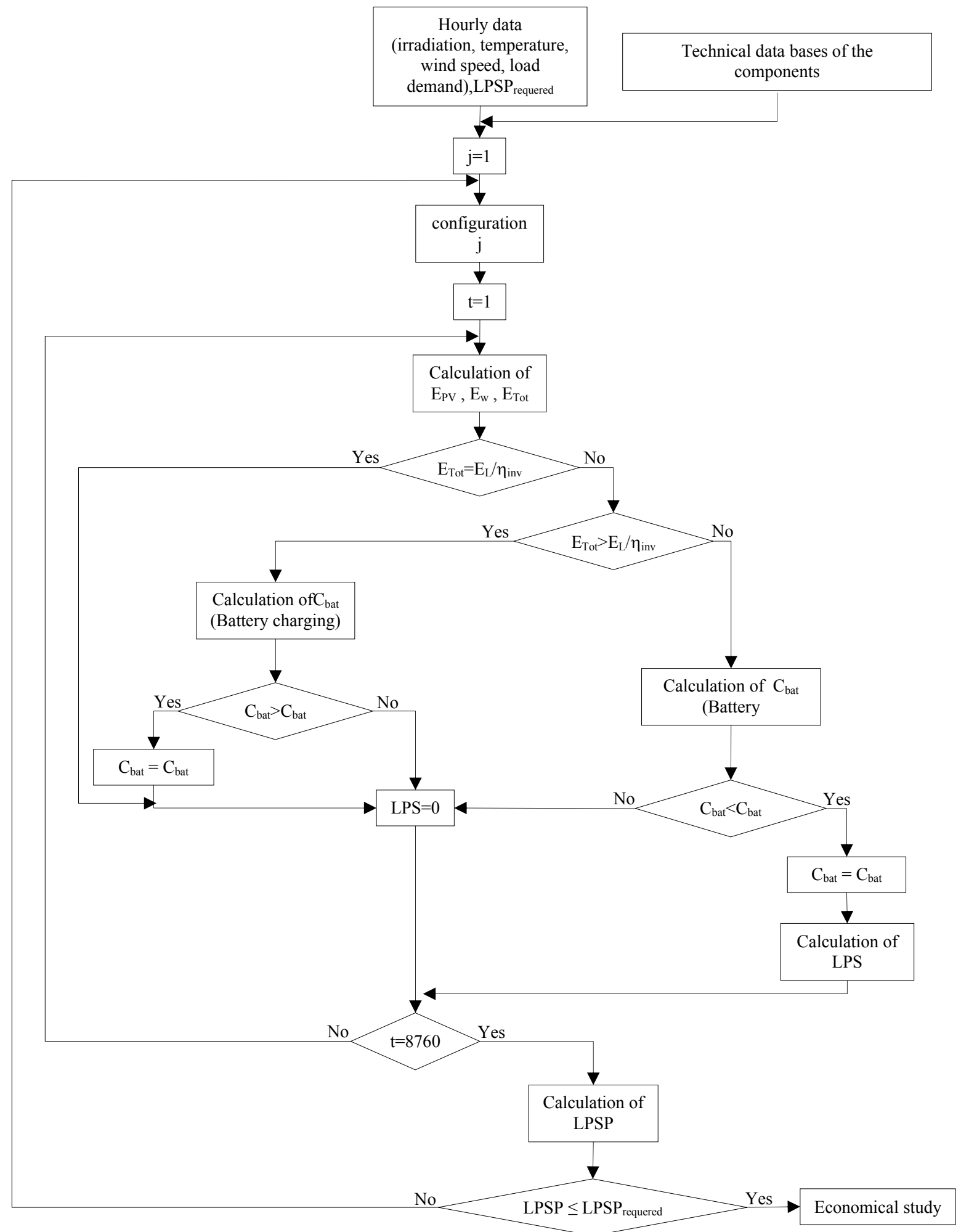

Fig. 2. Algorithm of the HPWS system operation simulation 

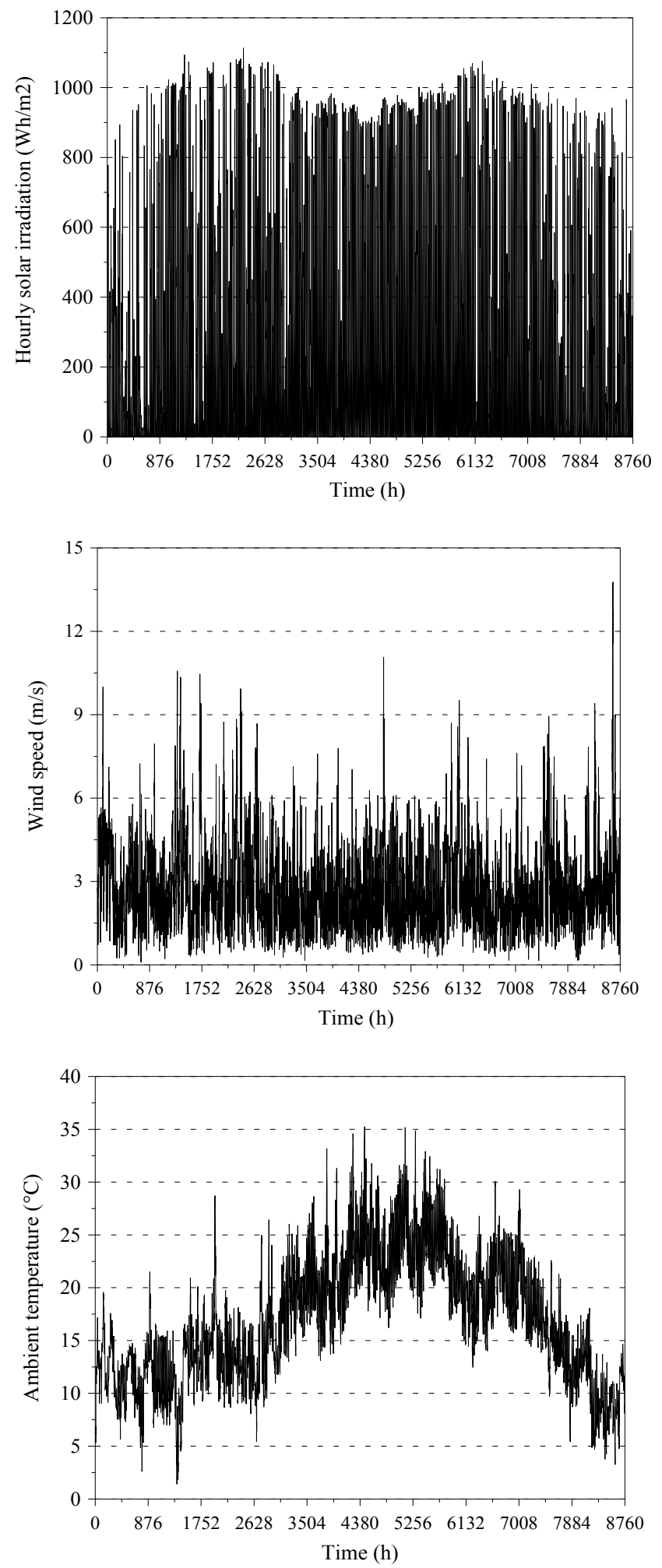

Fig. 3. Hourly values of meteorological parameters: (1) solar irradiation on titled plane (2) ambient temperature (3) wind speed 


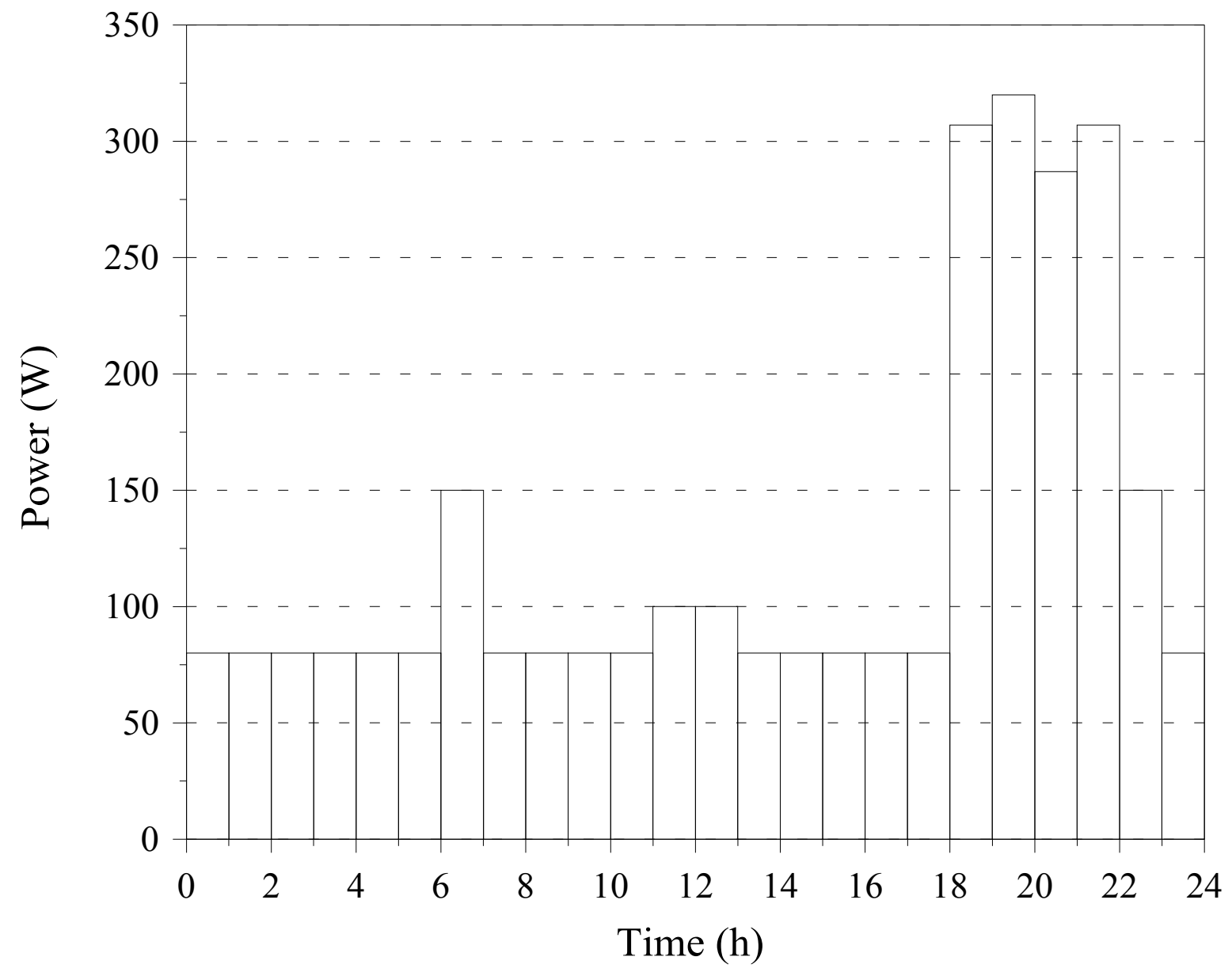

Fig. 4. Hourly load profile 


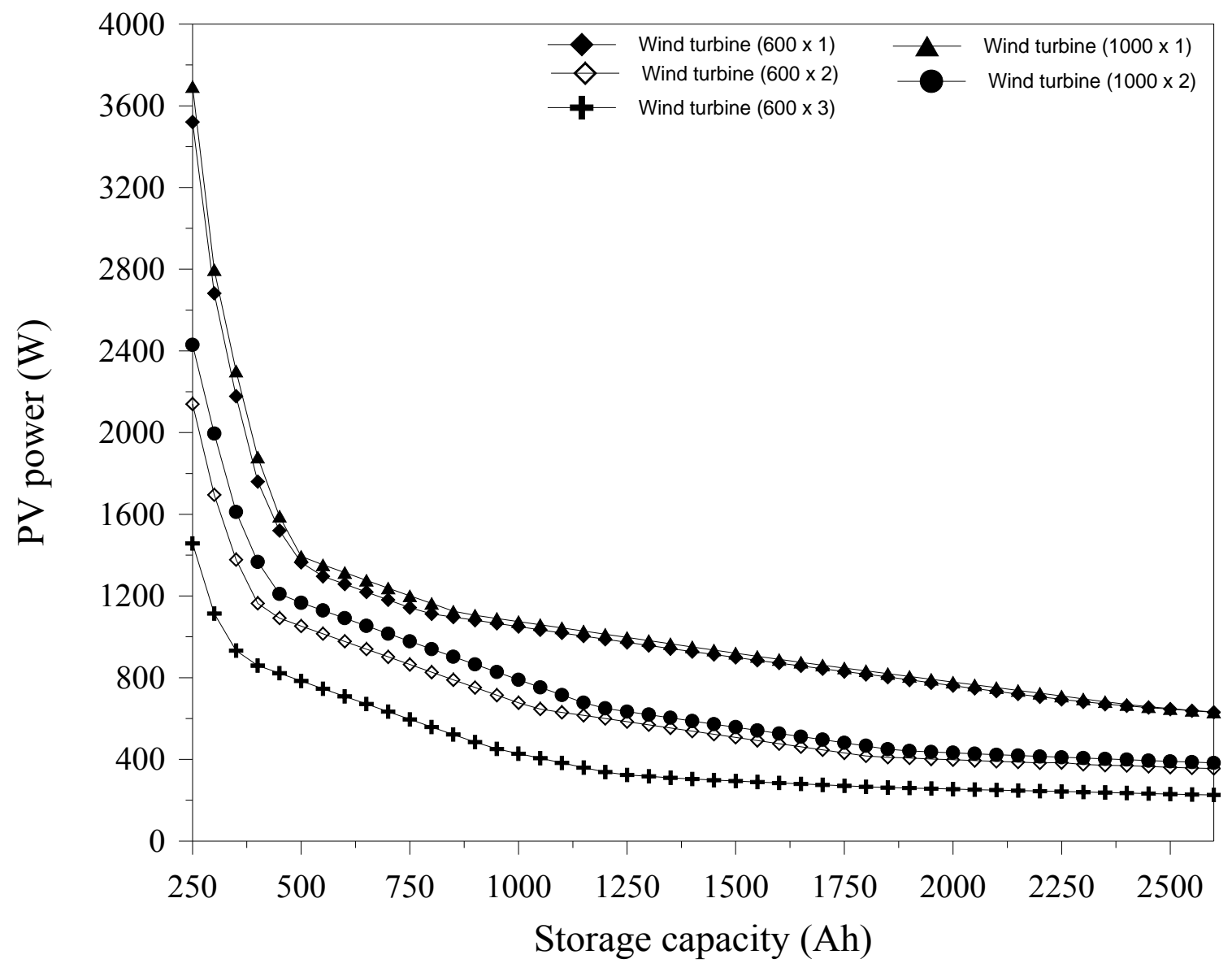

Fig. 5 . Hybrid system configurations for the desired LPSP of $0 \%$ 


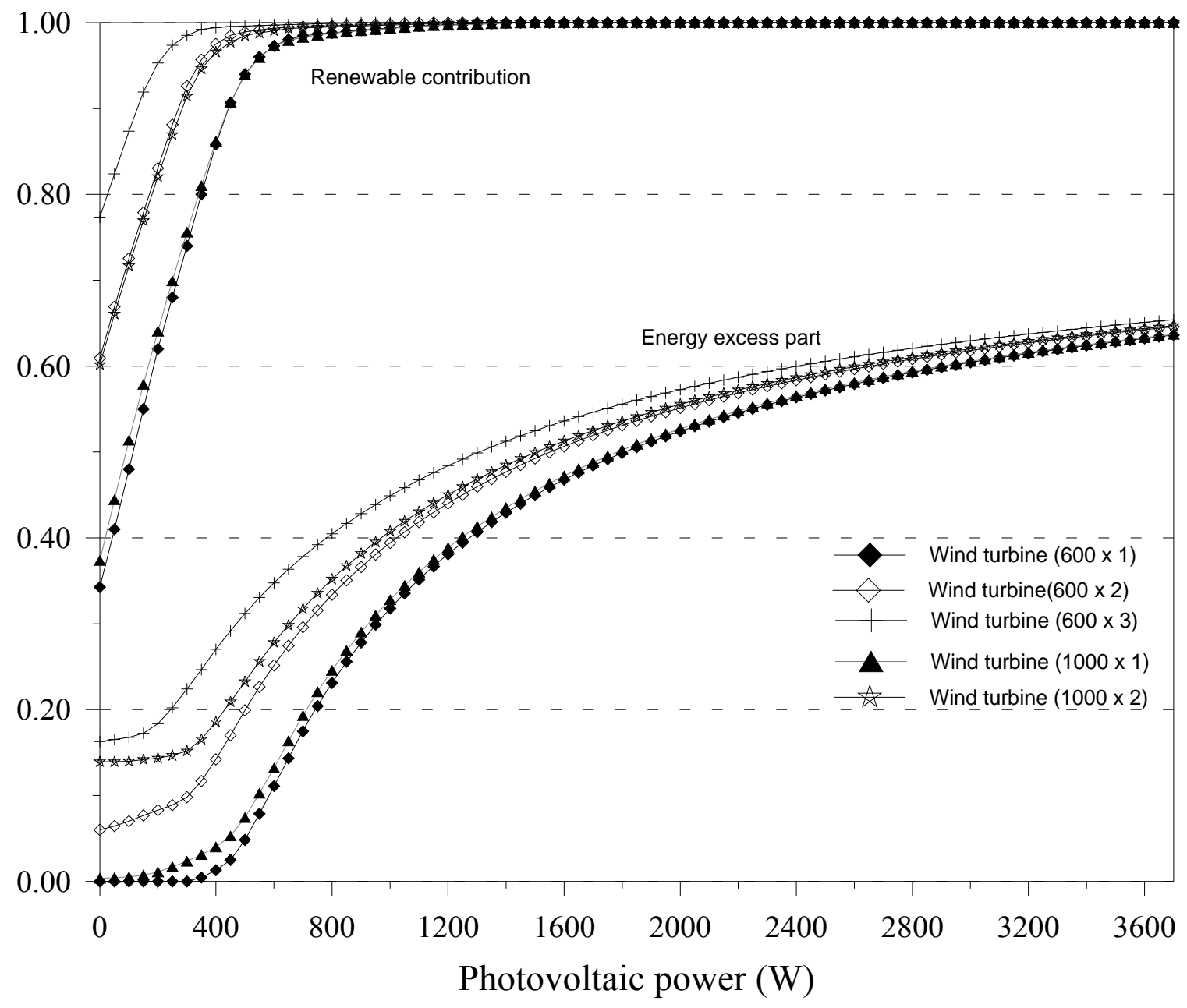

Fig.6 . Renewable contribution and excess part as a function of PV power for different Wind generators (1012 Ah of capacity storage) 


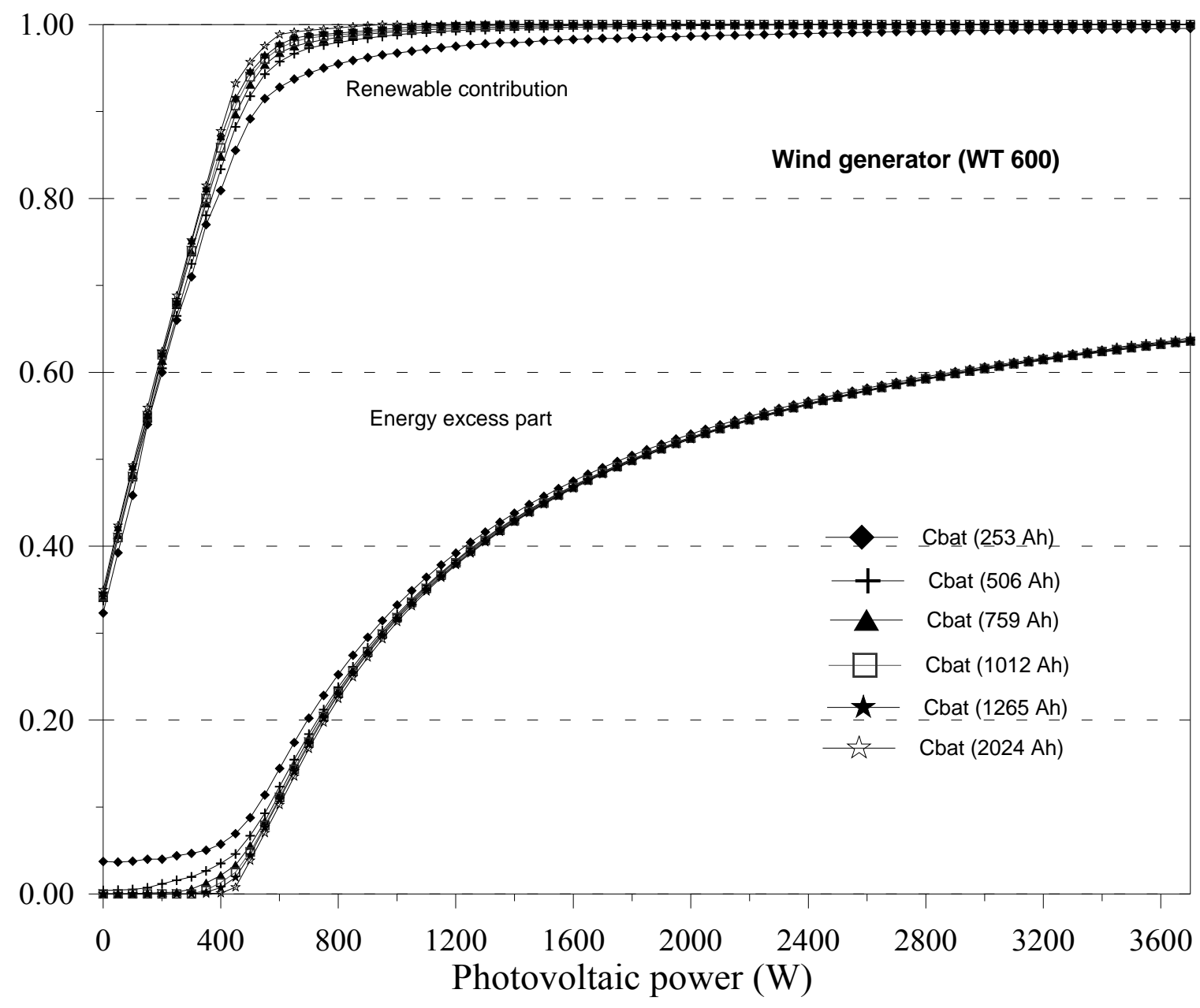

Fig. 7. Renewable contribution and excess part as a function of PV power 
(a)

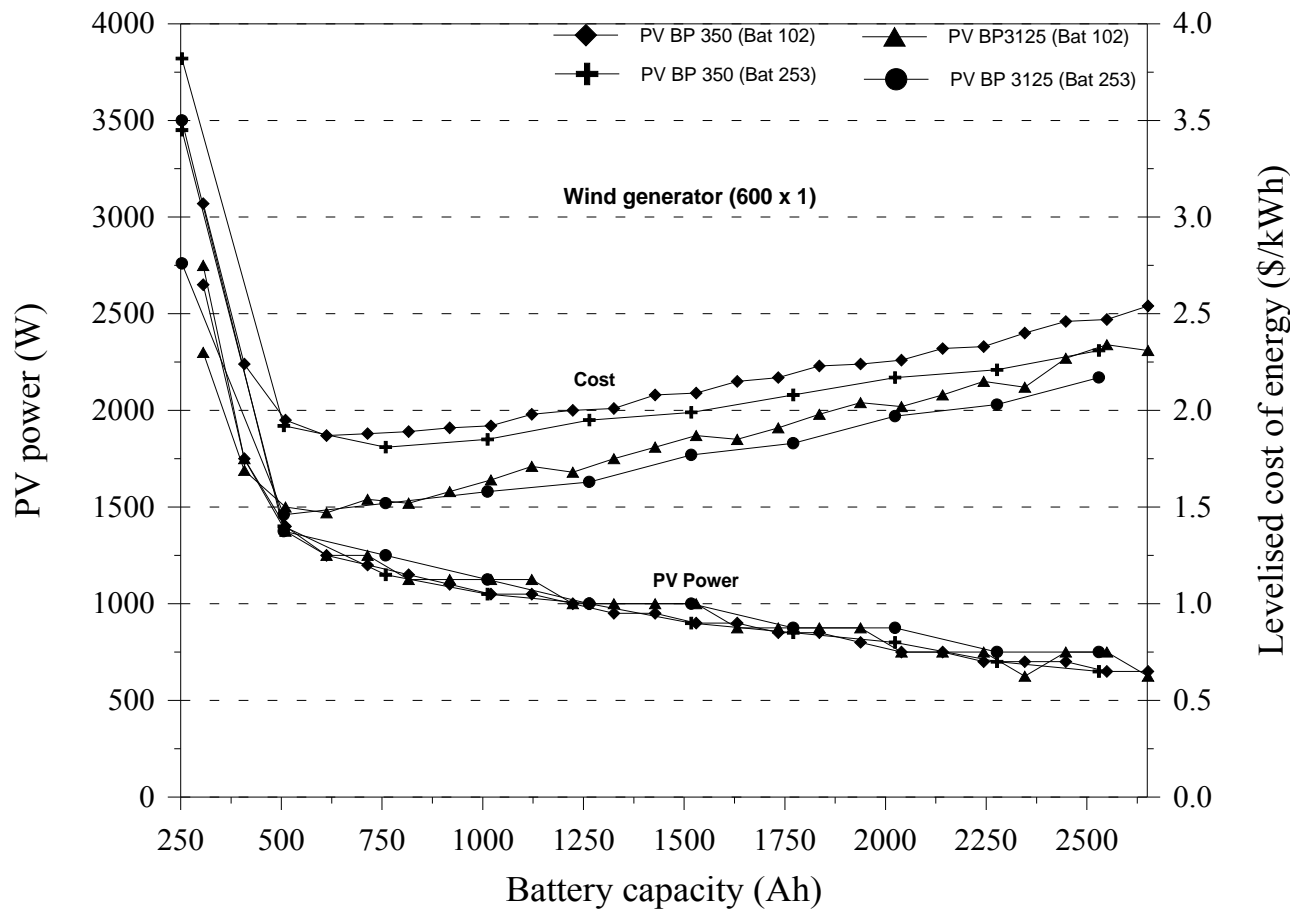

(b)

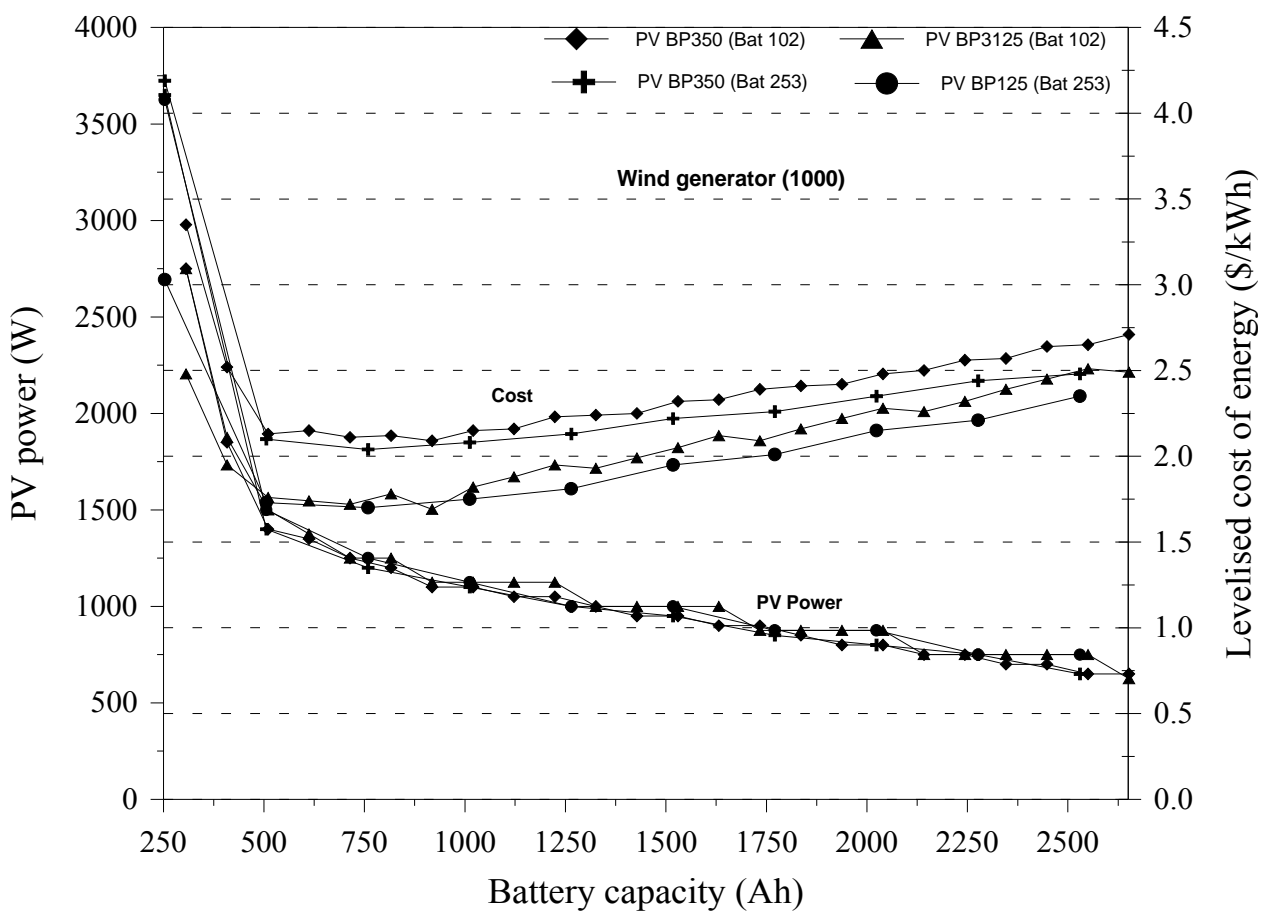

Fig.8 .Effect of components choice on levelised costs of energy for an LPSP of $0 \%$.

$\begin{array}{ll}\text { (a) Wind generator }(600 \mathrm{~W}) & \text { (b) Wind generator }(1000 \mathrm{~W})\end{array}$ 


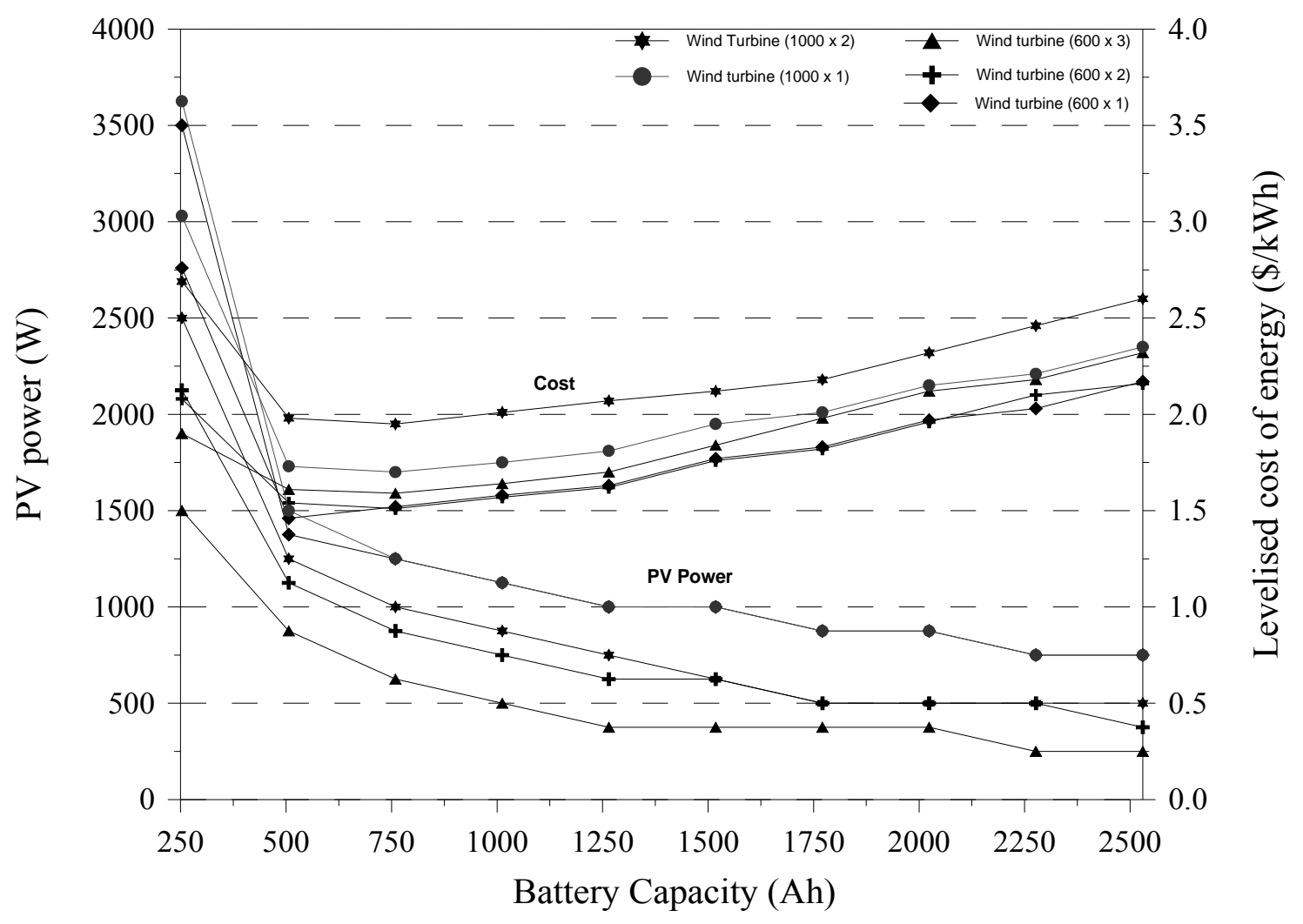

Fig. 9. Comparison of levelised costs of energy for different configurations (LPSP $=0$ ) 


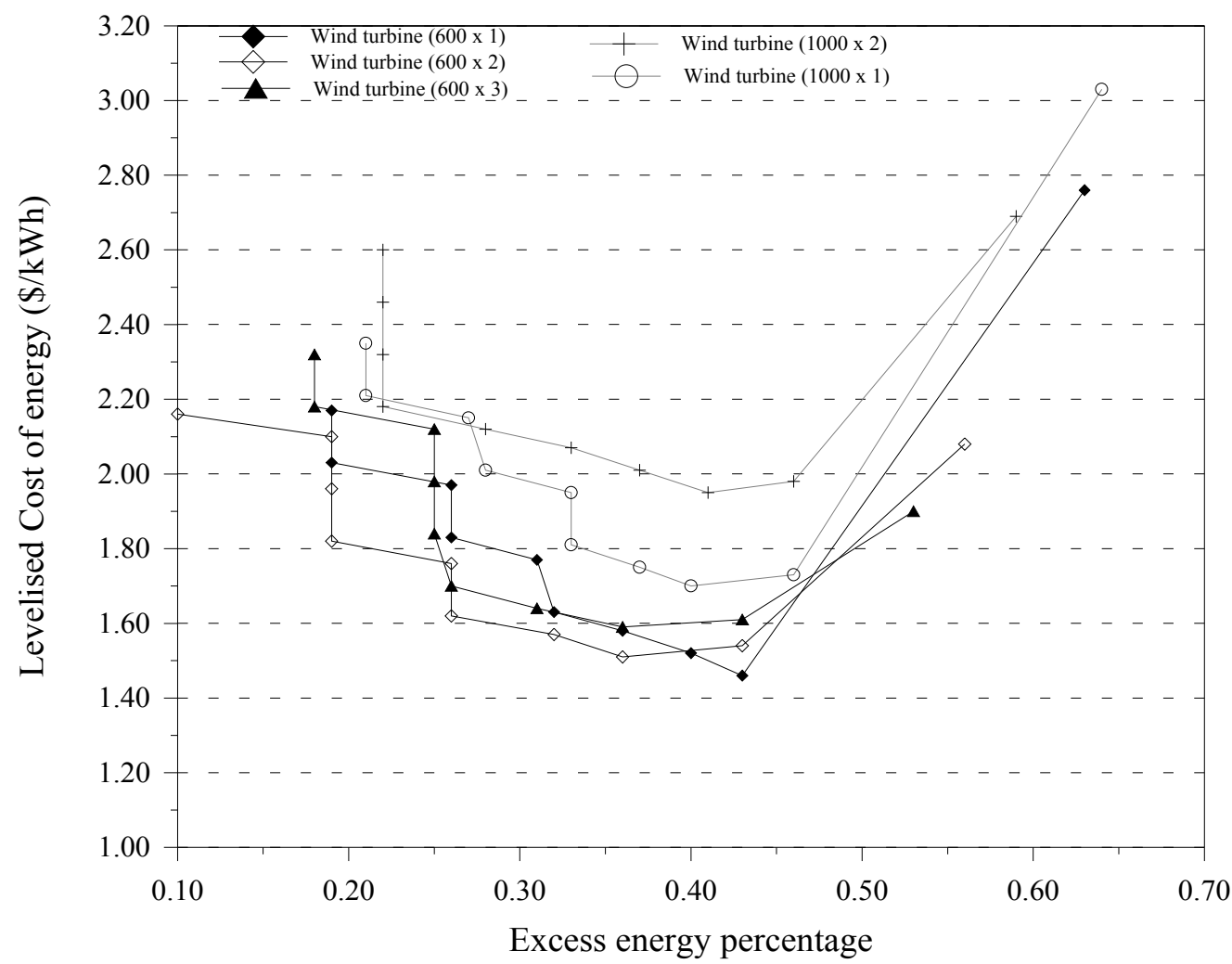

Fig.10. Levelised costs of energy as a function of energy excess part for optimal System configurations (LPSP $=0$ ) 
Table 1.

Photovoltaic modules parameters

\begin{tabular}{|c|c|c|c|c|c|c|c|c|c|}
\hline Type & $\begin{array}{l}P_{m p} \\
(W)\end{array}$ & $\begin{array}{l}\mathrm{V}_{\mathrm{mp}} \\
(\mathrm{V})\end{array}$ & $\begin{array}{l}\mathrm{I}_{\mathrm{mp}} \\
\text { (A) }\end{array}$ & $\begin{array}{l}\mathrm{V}_{\mathrm{oc}} \\
(\mathrm{V})\end{array}$ & $\begin{array}{l}\mathrm{I}_{\mathrm{sc}} \\
(\mathrm{A})\end{array}$ & $\begin{array}{c}\text { NOCT } \\
\mathrm{C}^{\circ}\end{array}$ & $\begin{array}{c}\mathrm{A}_{\mathrm{sc}} \\
\left(\mathrm{m}^{2}\right)\end{array}$ & $\begin{array}{c}\text { Price } \\
(\$)\end{array}$ & $\begin{array}{c}\text { BOS } \\
(\$)\end{array}$ \\
\hline ВР350 & 50 & 17.3 & 2.89 & 21.8 & 3.17 & $47 \pm 2$ & 0.451 & 350 & $50 \%$ of cost \\
\hline BP3125 & 125 & 17.6 & 7.1 & 22.1 & 7.54 & $47 \pm 2$ & 1.018 & 598 & $50 \%$ of cost \\
\hline
\end{tabular}


Table 2.

Wind turbines parameters

\begin{tabular}{ccccccc}
\hline Type & $\begin{array}{c}\text { Power rated } \\
(\mathrm{W})\end{array}$ & $\begin{array}{c}\mathrm{V}_{\mathrm{ci}} \\
(\mathrm{m} / \mathrm{s})\end{array}$ & $\begin{array}{c}\mathrm{V}_{\mathrm{r}} \\
(\mathrm{m} / \mathrm{s})\end{array}$ & $\begin{array}{c}\mathrm{V}_{\mathrm{co}} \\
(\mathrm{m} / \mathrm{s})\end{array}$ & $\begin{array}{c}\text { Price } \\
\$\end{array}$ & $\begin{array}{c}\text { BOS } \\
\$\end{array}$ \\
\hline WT 600 & 600 & 2.5 & 12 & 25 & 1500 & $25 \%$ of cost \\
BWCXL1000 & 1000 & 2.5 & 11 & 25 & 2500 & $25 \%$ of cost \\
\hline
\end{tabular}


Table 3.

Battery parameters.

\begin{tabular}{ccccc}
\hline Type & $\begin{array}{c}\text { Nominal capacity } \\
(\text { Ah) }\end{array}$ & $\begin{array}{c}\text { Voltage } \\
(\mathrm{V})\end{array}$ & Minimum charge & $\begin{array}{c}\text { Cost } \\
(\$)\end{array}$ \\
\hline Concorde (PVX 890T) & 102 & 12 & $20 \%$ & 208 \\
Concorde(PVX-2120L) & 253 & 12 & $20 \%$ & 465 \\
\hline
\end{tabular}


Table 4.

Hybrid system optimal sizing results (PV 125 W/ Battery 253 Ah)

\begin{tabular}{cccccc}
\hline $\begin{array}{c}\text { Nbr of wind turbine } \\
(\mathrm{W})\end{array}$ & $600 \times 1$ & $600 \times 2$ & $600 \times 3$ & $1000 \times 1$ & $1000 \times 02$ \\
\hline $\begin{array}{c}\text { PV generator power } \\
(\mathrm{W})\end{array}$ & 1375 & 1125 & 875 & 1500 & 1250 \\
$\quad$ & & & & \\
$\begin{array}{c}\text { Battery Capacity } \\
(\text { Ah) }\end{array}$ & 506 & 759 & 759 & 759 & 759 \\
$\quad$ & 1.46 & 1.51 & 1.59 & 1.70 & 1.95 \\
$\begin{array}{l}\text { LCE }(\mathrm{kWh} \text { Cost }) \\
(\$ / \mathrm{kWh})\end{array}$ & & & & \\
\hline
\end{tabular}

